\title{
Scale Economies and International Trade in a Rapidly Growing Region
}

\author{
Byron L. David \\ The City College of N ew York \\ Mitchell H. Kellman \\ The City College of N ew York \\ Graduate Center of the City University of New York
}

\begin{abstract}
Scale is universally acknowledged as important in the determination of national comparative advantage. Paradoxically, attempts to associate empiri cal measures of scale economies and international trade volume have proved largely inconclusive, and often have been found to sport the "wrong" sign. We examine the trade-scale nexus in the context of East Asian NICs and "NextTier" NICs whose economies and exports have grown especially rapidly since the mid-1960s. In a cross section context we replicate the negative correlations typically found in the literature. By combining time section and cross section analyses we demonstrate significant positive correlations in a dynamic context, finding that the smaller the country the greater the scale economy gains for any given population increase. (JEL Classification: F 12)
\end{abstract}




\section{Scale Economies and International Trade}

The gains from trade associated with the exploitation of increasing scale economies are obvious. As pointed out as early as Ohlin [1933, p. 54] and Viner [1937, p. 480], increasing returns may be a source of national comparative advantage. Since Krugman's seminal paper in 1979, the influence of scale economies on the volume of international trade has been a dominant theme in the theoretical literature.

The state of empirical work on scale and trade has been recently summarized by a number of researchers. Niroomand and Sawyer noted that "...little empirical work has been done on the subject" [1989, p. 138]; and, referring to an array of research, Harrigan commented that "the inconclusiveness of this empirical literature is disconcerting" [1994, p. 322]. To the extent that some consensus may be found, it contradicts common wisdom: For example, Davis noted that "econometric work relating the share of intraindustry trade to proxies for scale economies has consistently shown the relation to be significantly negative" [1991, p. 5]. In his review of the empirical evidence from Computable General Equilibrium (simulation) M odels, Tybout [1993] found that the patterns of scale economy exploitation predicted by these models do not conform to "other evidence"; including a study of large Mexican manufacturing plants by Tybout and Westbrook [1992], which concluded that the decline in average costs was not generally associated with scale effects. Another recent study concluded that "we are left with the counter-intuitive conclusion that returns to scale do not influence trade" 〈F arrell [1991], p. 53〉.

It appears that most empirical studies to date suffer from one of three major deficiencies: First, they focus on the relationship between scale economies and some measure of intra-industry trade - typically the Grubel- 
Harrigan argued that "... for purposes of estimating the contribution of scale economies to the volume of trade, it is preferable to examine the volume of trade directly rather than to look at the proportion of intra-industry trade" [1994, p. 137].

The second weakness lies with the employment of various proxy measures for scale economies, such as midpoint plant shipments. It is known that each of the proxies used in the literature has a particular weakness, so that none have emerged as dominant 〈Deardorff [1984]〉. H arrigan suggested that inferences concerning the volume of trade and scale economies are "... sensitive to the choice of proxy" [1994, p. 327].

Finally, empirical studies tend to rely exclusively on cross sectional estimates. Inferences drawn exclusively from such data must be based on certain strong and perhaps unrealistic assumptions. For example, one must assume that the particular period chosen is typical if one is to accept the estimates as equilibrium values. Even if such an assumption were accepted as reasonable, in the context of a rapidly evolving technology, short-run parameter shifts or trends would not be observed.

The theoretical work in this area also has some basic limitations. While the degree of scale economies and capital intensity may be highly correlated, giving rise to results reflecting relative country factor endowments, the issue of how relative factor supplies interact with scale economies to determine comparative advantage is complex; and, to date, remains intractable. As noted by Markusen and Melvin [1981], models which simultaneously address the inter relationships of scale economies and other factors, such as factor price differentials, do not exist.

In this paper we re-examine the relationship between direct measures of firm-level scale economies (rather than various proxies) in the context of trade flows notable for their rapid growth and product composition shifts in 
demonstrated that economies of scale establish a comparative advantage for the large country in the production of the commodity which exhibits increasing returns to scale - an intuitive result. In a two good context it is demonstrated in Markusen \& M elvin [1981] that the autarky price of the good embodying economies of scale (internal to its industry) will tend to be lower in the larger country. This is elegantly derived from the observation that an increase in the supply of productive factors (characteristic of the relatively large country) will lead to a percentage increase in the capacity to produce $X$ which is greater than it is for $Y$ precisely because $X$ exhibits increasing returns. Figure 3 in Markusen \& Melvin [1981, p. 459], which clearly illustrates this point, is replicated in Appendix 2. The unambiguous inference drawn from this model is that the larger country is more likely to export the higher scale-economy good. ${ }^{1}$

In this paper we attempt to examine this insight empirically by calculating scale economies "embodied" in exports and focusing on marginal relationships utilizing multivariate time series regressions. Then, we combine these time section analyses with cross section analyses using changes in scale economies to shed light on a clearly intuitive proposition that is regularly contradicted or not observed in empirical studies: positive scale economies and trade competitiveness "should be" positively related. ${ }^{2}$

\section{Data Sources and Assumptions}

Our sample is a pooled set of annual trade vectors consisting of 101 products for the years 1965 to 1992 . The source of the data is OECD (Organiza-

1. The logical extension to a multi product model follows: Given any two goods each

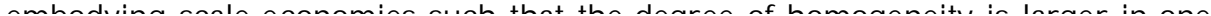


tion for Economic Cooperation and Development) Series C, "Trade by Commodity", processed by Data Resources Inc./ M cGraw-Hill. The vectors are from each of ten Southeast Asia exporters to the OECD countries, and are calculated separately for the original EEC, the US and J apan. The exporters fall into one of four groups:

* Japan

* China

* New Industrialized Countries (NICS): South Korea, Singapore, Taiwan and Hong Kong.

* ASEAN countries: M alaysia, Indonesia, Thailand, and the Philippines.

Each vector includes exports of all manufactured products at the 3-digit level for SITC Rev 1, from 512 through 899, for a total of 101 products for each of the 28 years.

Thus, the trade data include 10 exporters $X 3$ markets $X 28$ years $X 101$ products (for 92 of which scale elasticity data is available)

The second set is annual macroeconomic data from 1968 to 1990 for each of the ten Southeast Asian exporting countries, and is taken from the Penn World Tables 〈Heston and Summers [1993]〉. This includes observations on country population, exchange rates, and gross national products.

Finally, the third set of data, the actual scale economy elasticities, are those estimated by Niroomand and Sawyer [1989] for the years 1963 and 1980, following the methodology of Hufbauer [1970, pp. 176-181]. ${ }^{3}$ For the sake of brevity, we will not replicate the derivation of these elasticities, but merely emphasize that they are calculated via actual regression estimates of value-added per employee for various size U.S. companies representing 92 internationally traded products.

Our set of East Asian exporters was chosen for its members' unusually 
a large number of countries which experienced continuously rapid international trade expansion over a relatively long period of time, and represents a wide diversity of per-capita incomes, population sizes, and export orientations. Also, the large traded commodity sample allows for statistically meaningful subsets - in our case, products whose production process is characterized by positive scale elasticities.

\section{The Empirical Background}

Before examining the detailed relationships describing the trade-scale interactions, it is useful to present the actual levels and changes over time of the average scale elasticities characterizing each country's export vector. Using the published scale elasticities calculated by $\mathrm{N}$ iroomand and Sawyer [1989] for the year 1980, for each of 92 product groups; we weighted these by each product's annual export value. The relevant export-embodied scale elasticities for each country are presented in Figure la-d. In Figure la we note that over time, Japan's exports were increasingly more heavily weighted in high scale-elasticity products. Though in 1968 scale economies were more heavily represented in its imports, by the mid 1970s its exports were clearly more typically represented by large-scale economy products. This is a pattern typical of industrialized or developed country exporters during the period studied.

Figure $1 b$ compares the changes in scale-economy embodiments in the export vectors of the most highly developed and richest of the East Asian exporters to the U.S. market, China and Japan. As noted above, Japan's exports were relatively heavily weighted in products possessing positive scale-economy elasticities; and this tended to increase somewhat over time. China, on the other hand, experienced a period from 1968 to the mid-1970s 


\section{Figure 1a}

Scale Elasticity E mbodiments

Japan Exports and Imports

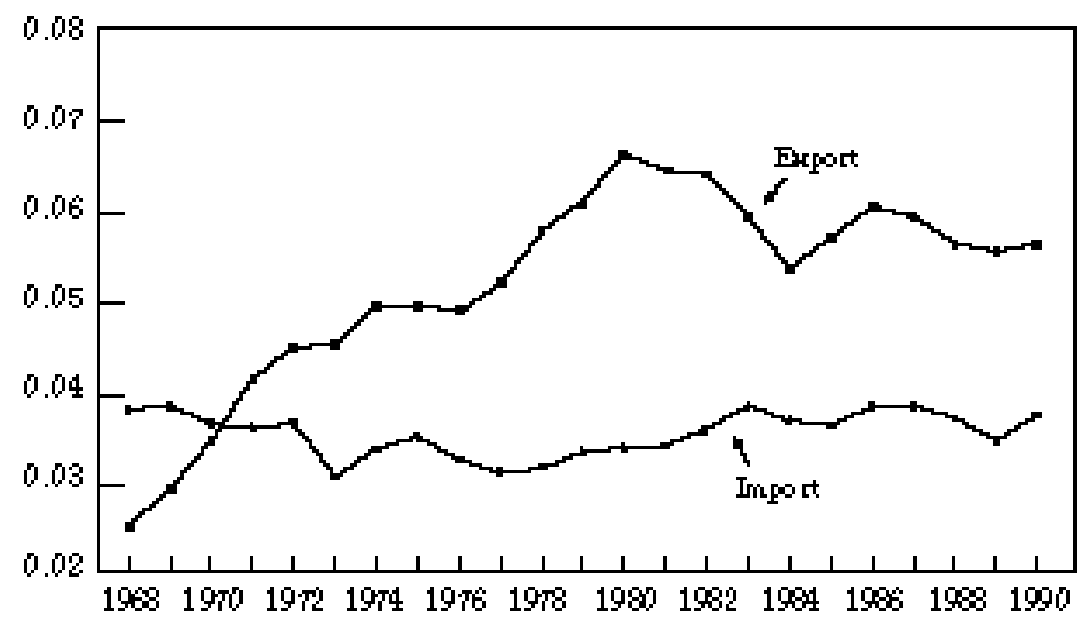

Figure 1b

Scale Elasticity Embodiments

China and J apan Exports

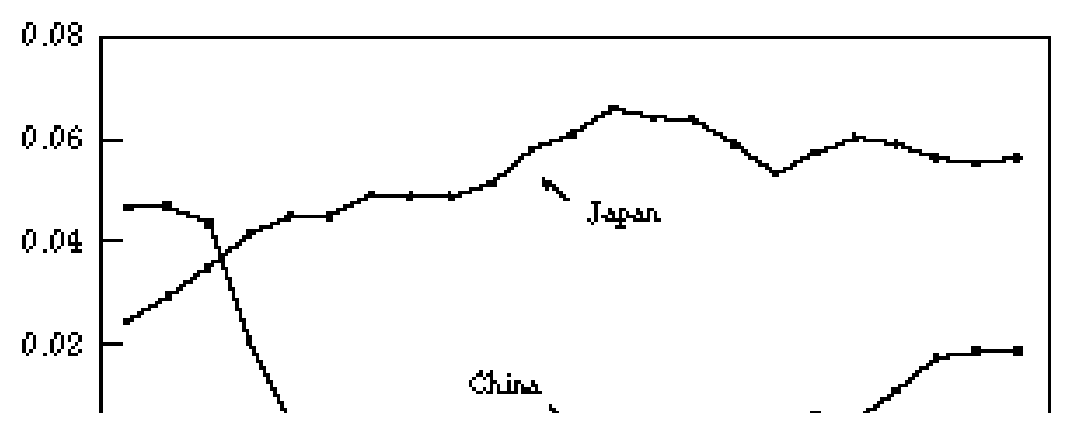


Figure 1c

Scale Elasticity Embodiments

NIC Exports

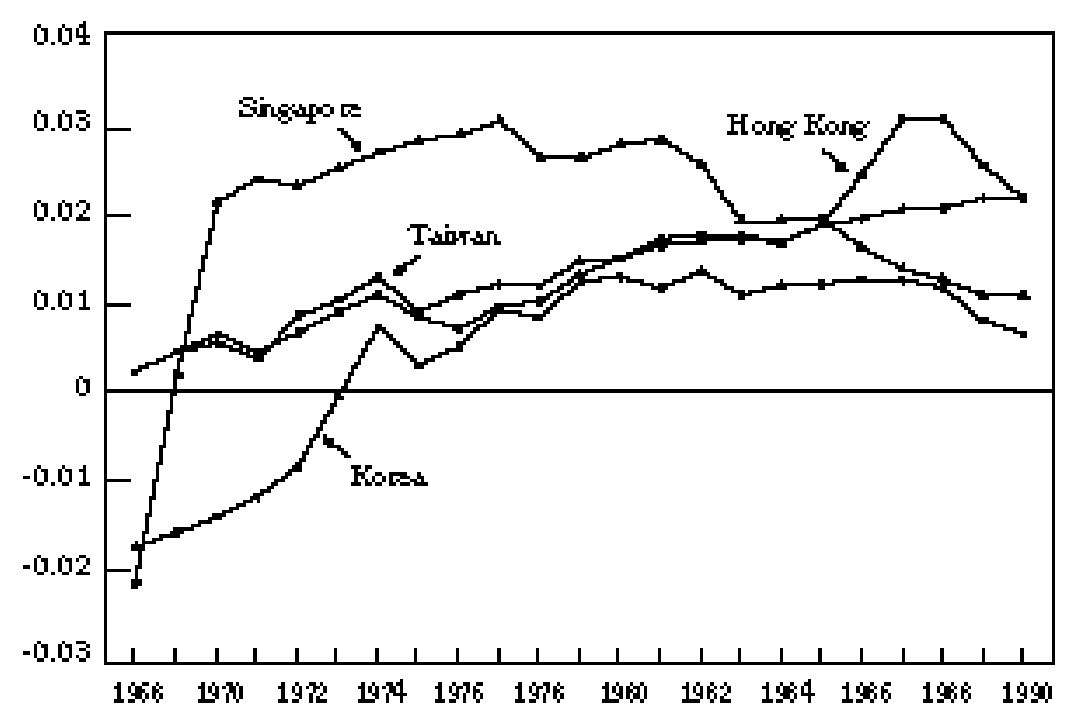

Figure 1d

Scale E lasticity E mbodiments

ASEAN Exports

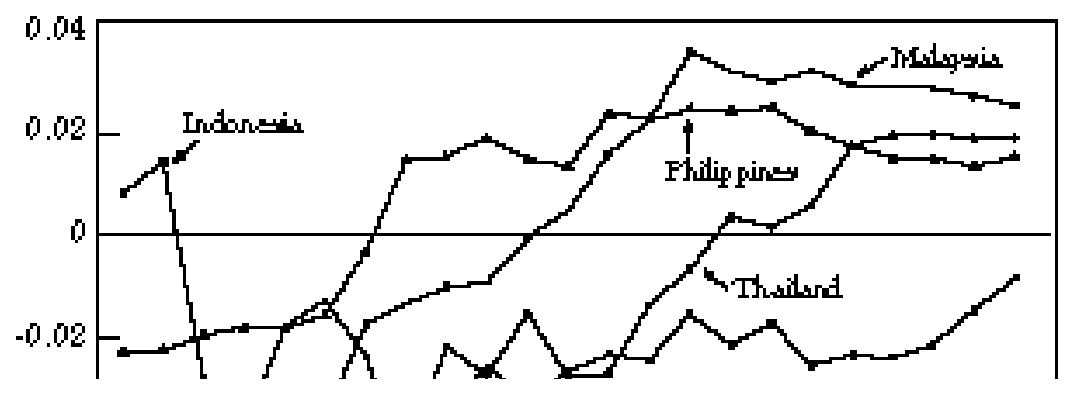


Korea, and Taiwan. In the late 1960s the export elasticities of Singapore and South Korea were negative, and close to zero for the other two. During the entire period the average scale elasticities rose for each of these four, until the mid-1980s. From then until 1992 they continued rising for South Korea and Taiwan, and fell slightly for the two city-islands .

Finally, Figure 1d describes the relevant scale economy elasticities for the four ASEAN countries - Indonesia, M alaysia, Philippines and Thailand. Compared with the NIC results, the ASEAN exports clearly embodied lower scale economy elasticities. All averaged negative scale elasticities from early to mid-1970s, and it was not until the mid-1980s that three of the four averaged (very low) positive scale economies. Indonesia shifted to manufactured products embodying increasingly lower scale economies and remained the only one with a negative average scale index in 1992. Thailand was the only one with a long term continual shift to higher and higher scaleeconomy exports. Both M alaysia and the Philippines peaked in the mid1980 s and shifted somewhat downward thereafter.

Table 1 summarizes some of the above results for easy comparison between the different country groupings.

On the whole, the results above support the conventional wisdom. Of all the East Asian exporters, the most advanced, Japan, with the highest per

Table 1

The "Returns-to-Scale" E mbodiments of Various Export Vectors

\begin{tabular}{|c|c|c|c|}
\hline & & \multicolumn{2}{|c|}{ Scale Economies Embodied in Exports } \\
\hline \multicolumn{2}{|l|}{ from } & U.S.A. & E.E.C. \\
\hline I Ianan & 1968 & .0253 & .0321 \\
\hline
\end{tabular}


capita income, exhibits the highest positive scale elasticities embodied in its export composition in both the U.S. and the E.E.C. markets. Conversely, in 1968, the relatively poor NIC and ASEAN exporters exhibited negative scale elasticities in their exports. Both regions which experienced fairly large per capita income increases during the period studied also experienced fairly dramatic increases in the average scale economies embodied in their exports to the two major OECD markets. In 1992, China, with the largest total market had larger average scale economies in its exports than did the other East Asian exporters (except J apan).

The relative magnitudes, and the changes over time of embodied scale economies support the intuitive conclusion of the theoretical models mentioned above: Scale economies may have played a significant role in aiding the dramatic export boom observed in this region over the period examined 〈see Chow and Kellman [1993]〉.

\section{Scale Economies and Country Size}

Is there indeed a tendency for relatively large countries to specialize in products characterized by relatively large scale economies? Table 2 pre-

Table 2

Mean Population and Mean Export Scale Elasticity 1968-1992

\begin{tabular}{|l|c|c|}
\hline \multicolumn{1}{|c|}{ Country } & $\begin{array}{c}\text { Population } \\
(1,000 \text { persons })\end{array}$ & Scale Elasticity \\
\hline China & 964,758 & .0064 \\
Indonesia & 144,981 & -.0216 \\
Japan & 114,557 & .0524 \\
Dhilinninac & 17770 & $n n 71$
\end{tabular}


sents the ten East Asian exporters ranked by population size ${ }^{4}$ and the average scale economies embodied in their exports to the U.S.

From the mean values above it appears that no significant statistical relationship connects country size with mean export scale elasticity - the rank correlation between these two is a statistically insignificant .32 .

However, it is quite possible that during a period of rapidly increasing exports, a significant relationship may exist between changes in population size and changes in the scale economies embodied in country export vectors. This possibility was tested by regressing over time each country's export scale elasticity on country population and on two other variables which could reasonably be expected to have an effect on the degree to which a country's exports embody scale economies. These two additional explanatory variables were per capita income and the exchange rate. The former was included since it is well known that scale economies tend to be significant in the international trade of richer countries. The latter was included since a change in a country's exchange rate over time tends to affect its international competitiveness across the product spectrum, hence opening up export opportunities which may through increased specialization exploit latent scale economies. The regression estimated for each country over the period 1968-1992 was:

$$
\begin{gathered}
\text { SCALEECONOMY }=a+b_{1}(\text { POPULATION })+b_{2} \text { (PERCAPITAINCOME) } \\
+b_{3}(\text { EXCHANGERATE })
\end{gathered}
$$

4. The paper utilizes population rather than GDP as the scale variable of choice. This was done for several reasons. The population variable is directly related to the labor force size and hence production potential of a country. This is especially true in a region enjoying rapid economic growth with relatively high education levels in both rich and poor countries. Furthermore, the specification we chose includes per capita income, as an important indicator of the level of economic sophistication of the coun- 
Table 3

Time-Series Regression Coefficients -

Dependent Variable 1980 Scale Elasticity 1968-1992

\begin{tabular}{|c|c|c|c|c|}
\hline \multirow{2}{*}{ Exporter } & \multicolumn{4}{|c|}{ Coefficients } \\
\hline & $b_{1}$ & $b_{2}$ & $b_{3}$ & $\mathrm{R}_{2}$ \\
\hline China & $\begin{array}{l}-.56 \\
(.001)\end{array}$ & $\begin{array}{c}.0002 \\
(.007)\end{array}$ & $\begin{array}{l}.0062 \\
(.55)\end{array}$ & .59 \\
\hline Indonesia & $\begin{array}{l}-3.17 \\
(.008)\end{array}$ & $\begin{array}{c}.0002 \\
(.024)\end{array}$ & $\begin{array}{l}.0000 \\
(.04)\end{array}$ & .81 \\
\hline Japan & $\begin{array}{l}2.98 \\
(.001)\end{array}$ & $\begin{array}{r}-.0000 \\
(.001)\end{array}$ & $\begin{array}{r}.000 \\
(.20)\end{array}$ & .84 \\
\hline Philippine & $\begin{array}{l}3.63 \\
(.178)\end{array}$ & $\begin{array}{r}.0000 \\
(.802)\end{array}$ & $\begin{array}{c}-.003 \\
(.30)\end{array}$ & .81 \\
\hline Thailand & $\begin{array}{l}5.62 \\
(.001)\end{array}$ & $\begin{array}{c}-.0000 \\
(.104)\end{array}$ & $\begin{array}{c}-.001 \\
(.88)\end{array}$ & .96 \\
\hline S.Korea & $\begin{array}{l}6.65 \\
(.001)\end{array}$ & $\begin{array}{c}-.0000 \\
(.013)\end{array}$ & $\begin{array}{c}-.000 \\
(.15)\end{array}$ & .95 \\
\hline Taiwan & $\begin{array}{l}3.49 \\
(.001)\end{array}$ & $\begin{array}{r}-.0000 \\
(.572)\end{array}$ & $\begin{array}{c}-.000 \\
(.58)\end{array}$ & .95 \\
\hline M alaysia & $\begin{array}{l}9.33 \\
(.004)\end{array}$ & $\begin{array}{r}.0000 \\
(.276)\end{array}$ & $\begin{array}{c}-.056 \\
(.01)\end{array}$ & .96 \\
\hline Hong Kong & $\begin{array}{c}13.54 \\
(.001)\end{array}$ & $\begin{array}{c}-.0000 \\
(.005)\end{array}$ & $\begin{array}{c}-.001 \\
(.17)\end{array}$ & .73 \\
\hline Singapore & $\begin{array}{l}-5.70 \\
1 \mathrm{nmmi}\end{array}$ & $\begin{array}{l}-.0000 \\
,\end{array}$ & $\begin{array}{l}-.046 \\
\ln _{n 11}\end{array}$ & .28 \\
\hline
\end{tabular}


register significant coefficients were the Philippines and Singapore.

Focusing on these significant coefficients, and recalling that the countries in Table 3 are ranked by population, we note a clear pattern: the larger the country, the smaller tends to be the coefficient - i.e., the smaller the shift towards higher-scaled export products associated with a given increase in population. This was found to hold for all of the countries with significant coefficients for $b_{1}$, with the sole exception of Taiwan.

The pattern in Table 3 is intuitively appealing. Let us assume that the average cost curve for any given product has the usual U-shape. If the demand for this product is at first assumed to be limited by the domestic market, then the smaller the country, the greater is the probability that demand will initially cut the average cost curve in the latter's descending portion. Furthermore, given the convexity of the cost curve - i.e., its typically positive second derivative with respect to output - the smaller the country the greater the probability that demand will intersect the average cost at a steeper (negative) portion of that schedule. In other words, the scale economy gains will tend to be greater for any given population increase the smaller the country - a pattern clearly supported by a Spearman (rank) correlation coefficient of .905 between population and the significant population coefficients.

Again referring to Table 3 , it is also noteworthy that for the two "giants" in the sample - China and Indonesia - the population coefficients are negative. That is, for these very large countries, further population growth does not appear to be at all related to any further international competitive gains associated with positive scale economies. This model suggests that the typical product in these huge countries is experiencing no dearth of domestic demand relative to its representative cost schedule. That is, the domestic demand equilibrium is already on the rising portion of the cost curve. 
Table 4

\section{Rank Correlations Between the 1963 Scale Elasticity (59 Products) and Exports}

\begin{tabular}{|l|l|l|l|}
\hline & 1966 & 1980 & 1992 \\
\hline China & & & -.31 \\
Indonesia & & & $-.22^{*}$ \\
Japan & & -.36 & -.40 \\
Philippines & & -.30 & -.29 \\
Thailand & & -.34 & -.31 \\
S. Korea & & -.31 & -.32 \\
Taiwan & $-.25 *$ & -.32 & \\
M alaysia & & & \\
Hong Kong & -.26 & -.24 & $-.24^{*}$ \\
\hline Singapore & -.26 & \\
\hline
\end{tabular}

Note: A blank indicates no significance; an asterisk $p<100$; otherwise $p<050$.

to be characterized by positive scale elasticities both in 1963 and in $1980 .^{5}$

Tables $4 \& 5$ summarize the rank correlation coefficients between product scale elasticities and export composition for each country. ${ }^{6}$ The former

5. The time series summarized in Table 3 above utilized all products for which scale economy data - negative or positive- were available. It utilizes (trade) weighted average scale figures and allows us to note the relationship over time of export product compositional shifts (from perhaps negative to positive or from positive to higher positive scale economies) with changes in population and other variables.

However, only positive scale products are included in the cross section study. This was done since the M arkusen \& M elvin [1981] model implies that a larger country has a relatively high probability of having a revealed comparative advantage in a product with positive scale economies. It is potentially relevant for any pairwise prod- 
Table 5

Rank Correlations Between the 1980 Scale Elasticity (59 Products) and Exports

\begin{tabular}{|l|c|c|c|}
\hline & 1966 & 1980 & 1992 \\
\hline China & & & -.30 \\
Indonesia & & $-.23^{*}$ & $-.22^{*}$ \\
Japan & & -.31 \\
Philippines & & & \\
Thailand & & -.31 & \\
S. Korea & & -.23 & -.28 \\
Taiwan & & \\
Malaysia & & & \\
Hong Kong & & & \\
Singapore & & & \\
\hline
\end{tabular}

Note: A blank indicates no significance; an asterisk $p<100$; otherwise $p<050$.

uses 1963 scale elasticities; the latter those from 1980. Table 6 summarizes the rank correlations between the $1963-80$ changes in scale elasticities and export product compositions for various years.

The results in Tables 4-6 above suggest that scale economies did indeed play a consistent role in enhancing the rapid manufactures export expansion experienced in the past roughly two decades.

In Table 4 we find negative correlations between measures of scale economies and export compositions for three of the Southeast Asian exporters. In these countries (Taiwan, Hong Kong and Singapore), the exports to the OECD in 1966 tended to be greater in products with smaller (positive) scale economies. The export compositions of the remaining seven countries were not significantly correlated with scale. 
elasticities. By 1992, seven countries had a significantly negative correlation, as compared to the original three.

Our results may indicate a growing tendency for the exploitation of the growth opportunities offered by the positive scale economies. Over time, the representative Southeast Asia countries exported larger volumes of products characterized by positive scale economies - as we saw in the time section analyses above - moving down the respective average cost curves to regions characterized by smaller (positive) scale economy potentials at the margin.

Focusing on the scale economies associated with the elasticities associated with the earlier period - the 1960's (in Table 4), all of the countries with significant cor relations were NICs - Taiwan, Hong Kong and Singapore. By the 1980s, and even more so by the early 1990s, the lower per capita income ASEAN "N ext-Tier NICs" were seen to have joined this process. By 1992, only two of the seven countries with significant cor relations were in the NIC category. Since the countries in Table 4 are ranked in descending order of size, it is of note that the process by which the export compositions tended to incorporate scale economies began in relatively small countries (whose domestic markets offered smaller potentials).

That the adjustment process tended to be rather lengthy is made clear by comparing the results in Table 5 with those in Table 4. In Table 5 we find that in terms of the relatively newer (early 1980s) technologies, fewer countries' export compositions were significantly correlated with the scale potentials. However, again we note the tendency for this process to migrate to a somewhat larger group of countries over time.

Thus, from Tables 4 and 5 we note that the relatively dynamic exporters of the region tended to exhaust the potentials offered by the scale economies, moving down to relatively lesser scale gains - the trend being led 
Table 6

Rank Correlations Between the Change in Scale Elasticity (59 Products) from 1963 to 1980 and Exports

\begin{tabular}{|l|c|c|c|}
\hline & 1966 & 1980 & 1992 \\
\hline $\begin{array}{l}\text { China } \\
\text { Indonesia } \\
\text { Japan }\end{array}$ & & $+0.23^{*}$ & $+0.22^{*}$ \\
$\begin{array}{l}\text { Philippines } \\
\text { Thailand }\end{array}$ & +0.26 & & \\
$\begin{array}{l}\text { S. Korea } \\
\text { Taiwan } \\
\text { Malaysia } \\
\text { Hong Kong } \\
\text { Singapore }\end{array}$ & & +0.30 & +0.26 \\
\hline
\end{tabular}

Note: A blank indicates no significance; an asterisk $p<100$; otherwise $p<050$.

Table 6 presents the correlations between the relative product compositions of each of the exporters, and the changes in the scale economies associated with the production process of each of the 59 products. Here, for the first time, we note the presence of positive correlations. Thus, in 1980 we find that South Korea, as well as China and Hong Kong, tended to specialize in exports of products whose scale economies increased the most between the mid1960s and early 1980s further indicating a tendency for the rapidly growing countries of this region to exploit export potentials created in part by technological shifts embodying positive scale economies. Though statistically significant, the correlations tend to be relatively small (ranging from .22 to .30), and remain insignificant for most of the countries examined. This cautions us to 
role of scale economies. We demonstrated that the degree of scale economies embodied in manufactures exports is systematically associated with the size of the exporting country - a general proposition hitherto derived from theoretical models and accepted as intuitively correct but never verified empirically.

Finally, we replicated the standard (anomalous) negative empirical relationships. We suggest that such findings may be explained in terms of a dynamic shifting model in which, on the one hand, exporters experiencing rapidly growing exports tend over time to systematically exhaust the potential gains offered by scale economies associated with given technologies; and, secondly, at the margin, tend to specialize in products undergoing increases in such scale economies associated with newer technologies. We also demonstrated the expected positive relationship between scale and trade in the context of a dynamic technology (or changing underlying scale economies).

\section{Appendix}

\section{Some Technical Notes}

Several technical points concerning our estimates concern possible misspecification errors associated with the use of the population variable.

It is possible that the high $\mathrm{R}^{2}$ 's associated with the individual country time series results summarized in Table 3 may reflect nothing more than time trends "embodied" in the population figures. As noted earlier in footnote 4, the population figures are derived from the Penn-Wharton (ICP) model, and are widely used by economists today. Nevertheless, since the use of population is relatively novel in the context of this paper, we will present the R2's 
Table A1

Coefficients of Variation and Durban-Watson Statistics Associated with Alternative Time Series Specifications

\begin{tabular}{|c|c|c|c|c|c|c|}
\hline & \multicolumn{2}{|c|}{$\begin{array}{c}\text { Using only } \\
\text { Population } \\
\text { (Table } 3 \text { above) }\end{array}$} & \multicolumn{2}{|c|}{$\begin{array}{l}\text { Using both } \\
\text { Population } \\
\text { and Trend }\end{array}$} & \multicolumn{2}{|c|}{$\begin{array}{c}\text { Replacing } \\
\text { Population } \\
\text { with National } \\
\text { Income }\end{array}$} \\
\hline & $R^{2}$ & DW & $\mathrm{R}^{2}$ & DW & $\mathrm{R}^{2}$ & DW \\
\hline China & .59 & .83 & .55 & .91 & .57 & .91 \\
\hline Indonesia & .81 & 1.76 & .81 & 1.89 & .72 & 1.03 \\
\hline Philippines & .81 & .75 & .89 & .83 & .79 & .61 \\
\hline Thailand & .96 & .78 & .95 & .97 & .89 & .85 \\
\hline S.Korea & .95 & 1.07 & .97 & 1.13 & .84 & .94 \\
\hline Taiwan & .95 & 2.20 & .98 & 2.20 & .97 & 2.35 \\
\hline M alaysia & .96 & .76 & .97 & .81 & .94 & .79 \\
\hline Hong Kong & .73 & 1.34 & .85 & 1.45 & .66 & .58 \\
\hline Singapore & .28 & .84 & .59 & .70 & .53 & .71 \\
\hline
\end{tabular}

countries in our sample had DW results falling within the acceptance zone (Indonesia, South Korea, and Hong Kong).

Second - Re-estimating the model with an added time trend did not notably improve or change the serial correlation, as noted by the DW statistics in the middle columns.

Finally - It might be argued that since many of the population figures may actually represent simple linear extrapolations from a small number of cen- 


\section{Appendix 2}

Figure 3 from Markusen and Melvin [1981]

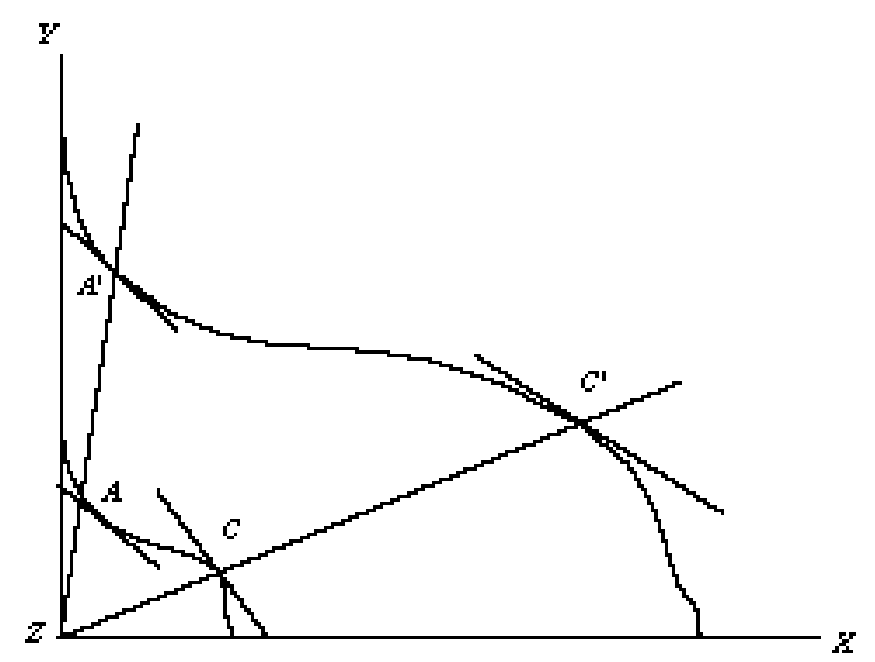

References

Chow, P. and Kellman, M ., [1993], Trade: The Engine of Growth in East Asia, $\mathrm{N}$ ew York, Oxford University Press.

Davis, D., [1991], "Intraindustry Trade: A Heckscher-Ohlin-Ricardo Approach," Columbia University Discussion Paper, N ov. 8.

Deardorff, A. V., [ 1984], "An Exposition and Exploration of Krueger's Trade Model," Canadian Journal of Economics, Nov, Vol. 7, No. 4; pp. $731-$ 746.

Farrell, M. J., [1991], "Industry Characteristics and Scale Economies as Sources of Intra-industry Trade," J ournal of E conomic Studies, Vol. 18, No. 4; pp. 36-58. 
International Trade," Journal of International E conomics, November, Vol. 9; pp. 469-480.

Markusen, J. R. and M elvin, [1981], "Trade, Factor Prices, and the Gains from Trade with Increasing Returns to Scale," Canadian Journal of Economics; pp. 450-682.

Niroomand, F. and C. W. Sawyer [1989], "The Extent of Scale E conomies in U.S. Foreign Trade," Journal of World Trade, Vol. 23, No. 6, Dec.; pp. 137-146.

Ohlin B. [1931], "Protection and Non-Competing Groups," Weltwirtschaft liches Archiv, Vol. 33; pp. 30-45.

Summers, R. And Heston, A. [1991], "The Penn World Table (M ark 5): An Expanded Set of International Comparisons, 1950-1988," Q uarterly Journal of Economics, M ay; pp. 327-368.

Tybout, J. R., [1993], "Internal Returns to Scale as a Source of Comparative Advantage: The Evidence," The American Economic Review: Papers and Proceedings, M ay; pp. 440-444.

Viner, J., [1955], Studies in the Theory of International Trade, London, George Allen and Unwin. 